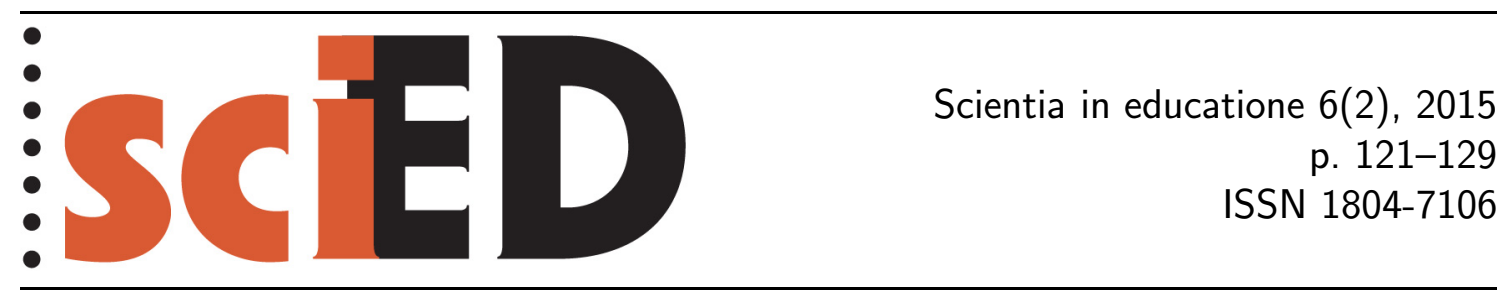

\title{
Redefinícia mólu - pozadie zmien v SI sústave a ich vplyv na vzdelávanie
}

\author{
Romana Schubertová, L’ubomír Held
}

\begin{abstract}
Abstrakt
Predkladaný príspevok prepája aktuálnu diskusiu o redefinícii základných jednotiek SI sústavy s vyučovaním chémie. Plánovaná definícia mólu má byt založená na presnom stanovení Avogadrovej konštanty. Problémy, ktoré sú spojené s takýmto definovaním mólu, vychádzajú však aj zo samotnej histórie veličiny látkové množstvo. Jedným zo základných problémov tohto charakteru je, že látkové množstvo je spomedzi základných veličín jedinou diskontinuálnou veličinou, ktorej jednotka mól nebola zavedená na základe vlastností prírody, ale na základe ludskej dohody. Je teda otázne či je mól zaradený medzi základné jednotky SI sústavy logicky správne. Aj z tohto dôvodu je veličina látkové množstvo zaujímavá taktiež z didaktického hladiska, ktoré je v príspevku diskutované.
\end{abstract}

Klíčová slova: mól, látkové množstvo, redefinícia jednotiek, Avogadrova konštanta, didaktika chémie.

\section{The Redefinition of the Mole - the Background of Changes in the International System of Units and Their Impact on Education}

\begin{abstract}
This article connects an ongoing discussion about the redefinition of basic units in the International System of Units with the teaching of chemistry. The "new" definition of mole is to be based on the precise determining of Avogadro constant. However, problems related to this new definition have roots in the history of the quantity amount of substance itself. One of the main problems is the fact that the amount of substance is the only discontinuous quantity (from among basic quantities) whose unit 'mole' was not introduced in the International System of Units on the basis of properties of the nature, but only by human agreement. Thus, the question is whether the mole is correctly placed among basic units of the International System of Units. This is one of the reason why this quantity is also interesting from the didactic point of view. It is discussed in this article.
\end{abstract}

Key words: mole, amount of substance, redefinition of units, Avogadro constant, chemistry education. 
Organizácia Bureau International des Poids et Mesures (BIPM - Medzinárodný úrad pre miery a váhy), ktorej úlohou je zabezpečit celosvetovú jednotnost meraní a ich prepojenie na medzinárodnú sústavu jednotiek, sa chystá na pomerne rozsiahlu revíziu definície niektorých základných jednotiek SI sústavy. Podnetom pre zmeny je najmä existencia etalónu v prípade kilogramu (pretože jeho hmotnost' sa s časom mení). Zmeny sa tak dotknú aj jednotiek, ktoré sú od definície kilogramu závislé. Jednou z nich je mól, základná jednotka veličiny látkové množstvo. Nová definícia mólu má byt pomerne jednoduchá: „Mól (značka mol) je jednotkou látkového množstva špecifikovanej základnej častice, ktorou môže byt’ atóm, molekula, ión, elektrón alebo iná častica, či skupina častíc; jeho rozmer je stanovený fixáciou numerickej hodnoty Avogadrovej konštanty, ktorá je presne 6,022 $14129 \cdot 10^{23}$, ked' je vyjadrená v SI jednotke $\mathrm{mol}^{-1}$." (BIPM, 2013) ${ }^{1}$. Na rozdiel od predchádzajúcej definície, ktorá sa odvolávala na počet atómov uhlíka ${ }^{12} \mathrm{C} v$ jeho 12 gramoch, bude mól vyjadrený presným počtom častíc. Ten má zodpovedat hodnote Avogadrovej konštanty - teda jej najpresnejšiemu odhadu, ktorý bude stanovený v čase zavedenia zmien definície jednotiek. Táto definícia je v súhre s celou novou koncepciou SI sústavy - definovat všetky základné jednotky pomocou nasledovných, tzv. základných konštánt:

1. Frekvencia žiarenia atómu cézia 133 v pokoji pri teplote absolútnej nuly pri prechode medzi dvoma hladinami velmi jemnej štruktúry základného stavu $(\mathrm{Hz})$ - pre definíciu sekundy.

2. Rýchlost svetla vo vákuu $\left(\mathrm{m} \mathrm{s}^{-1}\right)$ - pre definíciu metra.

3. Planckova konštanta ( $\mathrm{J} \mathrm{s})$ - pre definíciu kilogramu.

4. Elementárny náboj $(\mathrm{C})$ - pre definíciu ampéra.

5. Boltzmanova konštanta $\left(\mathrm{J} \mathrm{K}^{-1}\right)$ - pre definíciu kelvina.

6. Avogadrova konštanta $\left(\mathrm{mol}^{-1}\right)$ - pre definíciu mólu.

7. Svetelná účinnost̉ monochromatického žiarenia s frekvenciou $540 \cdot 10^{12}$ hertz $\left(\mathrm{l} \mathrm{m} \mathrm{W}^{-1}\right)$ - pre definíciu kandely.

Kým v súčasnosti je kilogram definovaný pomocou spomínaného etalónu, jeho navrhovaná definícia znie nasledovne: „Kilogram, kg, je jednotkou hmotnosti; jeho velkost' je určená fixáciou číselnej hodnoty Planckovej konštanty, ktorá je presne $6,62606 X \cdot 10^{-34}$, ked' je vyjadrená $\mathrm{v}$ jednotke $\mathrm{s}^{-1} \mathrm{~m}^{2} \mathrm{~kg}$, čo je ekvivalent jednotky J s." (Price, 2011)2. Nová definícia kilogramu je teda okrem hodnoty Planckovej konštanty závislá aj od definícií metra a sekundy. Samotná navrhovaná koncepcia však už po svojom predstavení v roku 2007 (na konferencii o mierach a váhach CGPM, z franc. Conférence Générale des Poids et Mesures, boli stanovené podmienky, ktoré musia byt splnené pred prijatím nových definícií) vyvolala v odborných kruhoch rozsiahle diskusie, ktoré sú teoretického aj praktického charakteru. Hovorí sa $\mathrm{v}$ nich nielen o problémoch spojených s fixáciou základných fyzikálnych konštánt, ktorá je len tažko reverzibilná (Price, 2011), ale aj o strate súdržnosti sústavy SI (spomínaná definícia kilogramu pomocou metra a sekundy), náročnej realizácii jednotky kilogram či predpokladaných problémoch s ich sprístupňovaním študentom (Hill, 2011). Didaktické hladisko je zdôrazňované takmer v každom príspevku, ktorý sa týka kritiky navrhovaných zmien.

\footnotetext{
${ }^{1} \mathrm{~V}$ citovanej definícii sa jedná o hodnotu Avogadrovej konštanty, ktorá je uvedená v návrhu 9-tej brožúry SI sústavy a slúži tak na ilustráciu novej definície. Definitívna hodnota Avogadrovej konštanty má byt’ fixovaná pomocou jej najpresnejšie nameranej hodnoty práve pred redefiníciou.

${ }^{2}$ Symbol „X“ v numerickej hodnote Planckovej konštanty bude v novej definícii nahradený číslicami podla najpresnejšej determinácie jej hodnoty.
} 
Štúdium problematiky v našom prípade podnietili zmeny, ktorými prechádza obsah základného chemického vzdelávania na Slovensku. Kým doposial' sa v ňom pojmy látkové množstvo, mól a molárna hmotnoste nachádzali, od pripravenej revízie do základného (povinného) obsahu nepatria. V snahe zaujat’ stanovisko k zmenám vo vzdelávacom obsahu sme sa v prípade látkového množstva zamerali aj na štúdium definícií pojmov a ich vývoja. Prebiehajúce zmeny v definícii základných jednotiek tak poskytujú, vd’aka búrlivej diskusii v metrologických periodikách (a z nich najmä Accreditation and Quality Assurance), pohlad aj na samotnú existenciu veličiny látkové množstvo a historické pozadie jej vzniku. Odporcov voči novej definícii je totiž asi tak vela, ako tých, ktorí nesúhlasia ani so súčasným zaradením mólu medzi základné jednotky SI sústavy, pričom sú často tou istou osobou (napr. Price, 2010, 2011).

Ustanovenie medzinárodného systému základných veličín a ich jednotiek v sedemdesiatych rokoch prinieslo do vzdelávacích systémov množstvo didaktických problémov. Československé školstvo sa s nimi vyrovnávalo aj vd’aka paralelne realizovanej obsahovej prestavbe všetkých stupňov vzdelávacieho systému, ktorá začala v roku 1976 (Held, 2011). Snaha po exaktnosti, ktorá prináša so sebou niekedy mechanické prekopírovanie odborných definícií do vzdelávacích obsahov, však paradoxne nemusí viest k zlepšeniu vzdelávacích výsledkov. Naopak odkrýva celý rad didaktických problémov, ktoré napokon súvisia aj s nedoriešenou odbornou problematikou.

Sme presvedčení, že takýto scenár postihol aj jedinú „chemickúu veličinu v sústave základných veličín, ktorou je látkové množstvo spolu so svojou jednotkou mól.

Predkladaný príspevok má dva základné ciele. Na jednej strane súhrnne informovat širšiu odbornú verejnost o zmenách, ktoré sa chystajú v definícii jednotky mól. Na druhej strane poukázat na paralely, ktoré existujú medzi problémami vo vyučovaní mnohých pojmov a ich vývojom a problémami „odborného" hladiska, ktoré boli zviditelnené pomocou didaktickej rekonštrukcie ako výskumného prístupu, dominujúceho dnes v didaktikách prírodných vied.

\section{ZARADENIE JEDNOTKY MÓL DO SI SÚSTAVY AKO ZAČIATOK PROBLÉMOV}

Zavedenie mólu ako základnej jednotky SI sústavy (rok 1971) vychádzalo z využívania pojmu gramatóm a grammolekula v stechiometrii (Furió, 2000). Milton (2011) považuje za dôležitú udalost' v histórii mólu publikáciu Perrina, ktorá prezentuje jeho pohlad na grammolekulu: „Stalo sa bežným nazývat’ grammolekulou látky také množstvo látky, ktorá v plynnom stave zaberá rovnaký objem ako 2 gramy vodíka, pri rovnakom tlaku a teplote. Avogadrova hypotéza je potom rovná nasledovnému výroku: Akékolvek dve grammolekuly obsahujú rovnaký počet molekúl.“ (Milton, 2011, cit. podla Perrin, 1909). Pojem mól sa v zmysle gramatómu a grammolekuly používal aj pred jeho oficiálnym zaradením do SI sústavy, zodpovedal počtu „predmetov“, rovnajúcemu sa Avogadrovemu číslu. Hodnotu Avogadroveho čísla však nebolo potrebné poznat a mól ako pomenovanie určitého počtu predmetov slúžil najmä na komunikáciu výsledkov meraní (Price, 2010). V prípade praxe je totiž pre chemika dôležité vediet, že 2,06 g vodíka sa zlučuje s 15,999 g kyslíka, pričom nezáleží na volbe jednotky, ale na pomere hmotností (Meinrath, 2011). Z podobného uhlu pohl’adu, avšak so zdôraznením didaktického hladiska, sa na pro- 
blematiku pozerá Tifi (2012). Podla neho je pre žiakov prirodzený koncept „relatívny počet častíc", ktorý by mal predchádzat sprístupneniu pojmu mól, pričom žiaci pomocou neho môžu bez využívania pojmu mól riešit úlohy stechiometrického charakteru. Ak totiž relatívna atómová hmotnost udáva, kol'kokrát je jeden atóm tažšś od druhého, vypovedá zároveň aj o pomere počtu týchto atómov v takej istej hmotnosti vzorky. Napríklad ak má atóm prvku „A“ dvakrát takú vel'kú hmotnoste ako atóm prvku „B“, v 100 gramoch vzorky atómov prvku „B“ bude dvojnásobný počet atómov, ako v 100 gramoch vzorky atómov prvku „A“. Rozšírením tejto úvahy sa dostávame k podobnému záveru, ktorý vyslovil Perrin: „V hmotnostiach látok, ktoré sú rovné relatívnym hmotnostiam ich častíc vyjadrených v gramoch (teda kedysi gramatóm alebo grammolekula), sa nachádza vždy rovnaký počet týchto častíc."

Situácia sa podla Pricea (2011) predstavením mólu ako základnej jednotky (podla spomínaného autora dokonca termodynamického charakteru) zmenila. Mól už nezodpovedal veličine, vyjadrujúcej počet častíc, ale novovytvorenej veličine látkové množstvo. Price upozorňuje na to, že v súčasnej definícii látkové množstvo nevyjadruje počet častíc (ako sa všeobecne poníma), a to najmä z toho dôvodu, že jeho hodnoty sú kontinuálneho charakteru (nezáporné reálne čísla), pričom počet častíc je diskontinuálny a má konečnú hodnotu, vyjadrenú celým nezáporným číslom. K tejto problematike sa vyjadruje viacero autorov. Niektorí považujú látkové množstvo (ktoré by malo reprezentovat počet častíc) za jedinú diskontinuálnu veličinu spomedzi základných veličín (Johansson, 2011; Price \& De Bievre, 2009), iní hovoria o logických nedostatkoch súčasne prezentovanej Avogadrovej konštanty (Pavese, 2011; Barańsky, 2012). Tá je totiž vyjadrovaná aj so štandardnou neistotou, teda intervalom okolo odhadu meranej veličiny, v ktorom sa s určitou pravdepodobnostłou nachádza konvenčne pravá hodnota meranej veličiny. Situácia je spôsobená určením numerickej hodnoty Avogadrovej konštanty, ktorá nevznikla počítaním, ale nepriamou experimentálnou (empirickou) determináciou inej kontinuálnej veličiny - o vývoji metód odhadovania Avogadrovej konštanty a jej meraných hodnôt prehladne informovali napr. Chemické listy (Slavíček, 2012). Numerický výsledok tejto determinácie je vyjadrený ako nezáporné reálne číslo, z logického hladiska by však mal byt číslom prirodzeným (Pavese, 2011). Problém diskontinuity veličiny teda vo vel'kej miere súvisí aj s okruhom výhrad voči Avogadrovej konštante. Dostáva sa na povrch aj vo vyučovaní pojmov, kde je Avogadrova konštanta v učebniciach rôzne vyčíslovaná. Napríklad v učebnici pre 8. ročník ZŠS z roku 1991 (Šramko et al., 1991) je uvedené, že jeden mól: „... obsahuje približne $6,023 \cdot 10^{23}$ častíc, čo je 602300000000000000000000 častíc." V novších učebniciach (Vicenová \& Ganajová, 2012) je už slovo „približne“ vynechané, ale Avogadrova konštanta je vždy na ilustráciu vyčíslená s nulami. K tomuto problému Pavese (2011) dodáva, že vyjadrenie, že jeden mól obsahuje $6,02214129 \cdot 10^{23}$ častíc (ktoré sa nachádza v novo navrhovanej definícii mólu) nie je správne, nakolko značí, že ostatné desatinné miesta vo vyjadrení sú rovné nule. To, že zvyšné číslice nepoznáme, však neznamená, že sú rovné nule.

Z historického hladiska bol mól zavedený ako vyvrcholenie sporu medzi atomistami a ekvivalentistami (Furio, 2000). Kým ekvivalentisti uvažovali o zlučovaní a chemických reakciách v rovine makroskopickej, prostredníctvom ekvivalentových váh (historický pojem), atomisti na základe Daltonovho postulátu tvrdili, že v chemickej reakcii spolu reagujú zlúčeniny molekula k molekule. Podla Meinrahta (2011) sa však atomistický pohlad stal faktickou realitou a nie je teda dôvod zavádzat, prípadne využívat konštrukciu veličiny, ktorá dnes nemá reálne opodstatnenie. 


\section{PRIRODZENÁ ZÁKLADNÁ VELIČINA - POČET ČASTÍC}

Práve na základe diskontinuity veličiny, ktorá počíta častice, by mal byt’ logickou základnou jednotkou samotný kus (v angličtine využívaný pojem „unity“). Mól je $\mathrm{v}$ tomto prípade len matematickým násobiacim faktorom - faktorom mierky (Johansson, 2011). V prípade kontinuálnych veličín je otázkou konvencie, aká jednotka bude zvolená za základnú - je teda záležitostłou dohody, či označíme 1 kilogram za základnú jednotku a 1 gram za jeho alikvotnú čast, alebo opačne. Avšak záležitostłou dohody nie je, či považujeme 1 molekulu $\mathrm{H}_{2} \mathrm{O}$ za jednotku a tucet takýchto molekúl za jej násobok, alebo uvažujeme opačne. Kým 1 kilogram môžeme považovat za základnú jednotku alebo jej násobok, jeden tucet bude vždy len násobiacim faktorom určenej základnej jednotky. Mól by mal byt považovaný za takýto násobiaci faktor, kedže nie je viazaný na žiadny druh častíc a môže byt aplikovaný vždy, ked' sa jedná o diskontinuálne entity. Nespojité entity sú tak vlastnými jednotkami počítania. Potrebujú na svoje spočítanie len prirodzené čísla. Počítanie totiž vyžaduje, aby mal termín „nasledujúci v poradí“ zmysel. V prípade kontinuálnych veličín nie je možné tento termín používat, kedže medzi dvomi bodmi, akokolvek sú si blízko, sa vždy nachádza aj tretí bod. Z tohto dôvodu musia mat' kontinuálne veličiny jednotku miery stanovenú dohodou.

Zaujímavé je na tomto mieste spomenút, že podobný pohlad na túto záležitoste, ktorý je v poslednej dobe prezentovaný v zahraničí, sa vyskytol už pomerne dávno v osemdesiatych a devätdesiatych rokoch v Československu, ked' neúnavný Petera (1988) navrhoval za základnú jednotku látkového množstva (v Peterových návrhoch „mnohosti látky“) jednotku „indiv“. Bez „cimrmanovského“ sarkazmu možno konštatovat, že jeho tvrdenia sú konzistentné so súčasnými renomovanými autormi: „... ve své skutečné podstate totiž mol není ničím iným, než velmi velikým násobkem indivu, je tedy velkou měrnou jednotkou mnohosti." Citované vyjadrenie naráža na d’alší problém, s ktorým sa dnes opät stretávame. Mnohí autori vnímajú názov veličiny látkové množstvo ako mätúci. Je považovaný za rozvláčny, príliš všeobecný a nejednoznačný (Padilla \& Furio, 2000) či podla Peteru nevýstižný, svojou dvojslovnostou neoperatívny (Petera, 1988; Furio, 2000). Od začiatku existencie veličiny sa tak objavilo množstvo návrhov na vhodnejší názov - chemiancia, chemické množstvo, enplethia a iné. Z vyjadrení Miltona je však zretelné, že zmeny, ktoré majú byt podla BIPM v SI sústave vykonané, majú v čo najmenšom rozsahu ovplyvnit praktických užívatelov (Milton, 2011).

Na tomto mieste chceme opät upozornit na didaktické problémy, ktoré boli známe vzápätí po ustanovení novej veličiny a jej jednotky. Prehlad o riešeniach problematiky vyučovania daných pojmov sme poskytli pred tridsiatimi rokmi (Held, 1985). Náš návrh výkladu vychádzal z „kvantifikovaného opisu“ chemickej rovnice vyjadrujúcej syntézu vody: Pre praktickú činnost'v chemickom laboratóriu bude užitočné, aby sme si určili nejakú základnú jednotku, ktorou budeme vyjadrovat množstvo reagujúcich látok. Povedzme 1 miliarda častíc (molekúl). (Po prečitaní rovnice v miliardách reagujúcich molekúl sa prechádza na všeobecné bezmenné jednotky.) Rovnica potom vyjadruje: 2 jednotky množstva vodíka (predtým 2 miliardy alebo $2 \cdot 10^{9}$ ) +1 jednotka množstva kyslíka (predtým 1 miliarda alebo $1 \cdot 10^{9}$ ) reaguje za vzniku 2 jednotiek množstva vody (predtým 2 miliardy alebo $2 \cdot 10^{9}$ ). V praxi sa však zaužívala iná jednotka látkového množstva, ktorá obsahuje približne $6,022 \cdot 10^{23}$ častíc, namiesto nami uvažovaných $10^{9}$ častíc.

V uvedenom príklade je taktiež vyjadrená myšlienka, že je záležitostou dohody, aký velký počet častíc bude jednotka (následne predstavená ako mól) obsahovat. 
K tejto problematike podobne ako aj iní autori (napr. Price \& De Bievre, 2009) podotýkame, že hodnota Avogadrovej konštanty by bola odlišná, pokial by sa v čase zavádzania jednotky mól využívali na meranie hmotnosti iné jednotky ako gram (napr. libra - namiesto pojmov gramatóm a grammolekula by tak boli vytvorené pojmy libraatóm či libramolekula (približne 2,734·1026) (Held, 1985). Aj náš súčasný návrh sprístupnenia pojmov látkové množstvo a mól vychádza z predpokladu, že mól je násobkom jedného kusu (častice). Súčasne v ňom okrem nedoriešených odborných metrologických problémov reflektujeme aj aktuálne zavádzanie nových pojmov v prírodovednom vzdelávaní pomocou induktívnej metodológie (Schubertová, 2014).

\section{NAVRHOVANÁ DEFINÍCIA A SÚČASNÁ DISKUSIA OKOLO NEJ}

V súvislosti s plánovanou zmenou definície mólu sa objavujú názory, že nová definícia nevyrieši logické problémy veličiny a jej jednotky, ktoré sú s nimi spojené. V diskusiách bolo navrhované zavedenie viacerých veličín, jednotiek či novotvarov, ako napríklad „numerozita“ (z angl. numerosity, ako akási „početnost"“) (De Bievre, 2007; Rocha-Filho, 2011), ktorá sa nápadne podobá Peterovmu návrhu „mnohost““ (Petera, 1988), „avo“ a „ent" (Leonard, 2011a, 2011b, 2011c) alebo „uno“ (Mills, 1995). Tie však podla Miltona (2011) nemajú potenciál zasiahnut do plánovaných zmien v SI sústave. Navrhovatelia týchto zmien, ako oponenti súčasnej aj plánovanej definície, však často poskytujú zmysluplné argumenty, stojace za ich námietkami. Niektoré z nich vymenujeme:

- Nová SI sústava chce vychádzat z definovania jednotiek prostredníctvom základných fyzikálnych konštánt. Avogadrova konštanta však nie je základnou fyzikálnou konštantou v pravom zmysle slova (ako napríklad rýchlost' svetla vo vákuu). Je len špecifickým príkladom spomedzi mnohých, prirodzene sa vyskytujúcich stabilných javov (Price, 2011).

- Problémom definovania kilogramu je, že sa hodnota Planckovej konštanty v čase a priestore mení a zmeny hodnoty konštanty tohto charakteru tak môžu spôsobovat problémy v základnej metrológii (Hill \& Khruschov, 2013).

- Jedným z primárnych cielov SI sústavy bolo určenie základných, od seba navzájom nezávislých jednotiek. Vzájomná nezávislost jednotiek garantovala konzistenciu sústavy. Prvýkrát narušilo túto konzistenciu samotné predstavenie mólu, pretože jeho definícia zahŕňala kilogram, nasledovalo definovanie metra pomocou rýchlosti svetla atd’. Použitie fundamentálnych konštánt na definovanie jednotiek tak dovŕši elimináciu principiálnych rozdielov medzi základnými a odvodenými jednotkami (Pavese, 2011).

- Definičný problém sa týka aj daltonu (iný názov - atómová hmotnostná jednotka, značka Da alebo u), ktorý je v súčasnosti stanovený ako jedna dvanástina hmotnosti atómu uhlíka ${ }^{12} \mathrm{C}$. Pri nezávislej fixácii Planckovej konštanty (pomocou ktorej bude definovaný kilogram) a Avogadrovej konštanty (pomocou ktorej bude definovaný mól) bude pre dalton platit nasledovná definícia: Da =1/(1000 $\mathrm{N}_{A}$ ) kg presne (Leonard, 2011). Táto hodnota však nebude zodpovedat jednej dvanástine hmotnosti atómu uhlíka ${ }^{12} \mathrm{C}$. Na vyriešenie tejto situácie boli navrhnuté rôzne explicitné aj implicitné korekčné faktory.

Citovaní autori zároveň vyzývajú tvorcov „novej SI sústavy“ na širšiu diskusiu s odborníkmi, ktorá zatial', aj napriek príslubom, neprebehla (Hill \& Khruschov, 
2013). Od návrhov novej sústavy (v roku 2007) pritom prebehlo už niekolko rokov a plány na jej prijatie spadajú do roku 2018 (Richard \& Ullrich, 2014).

\section{NA ZÁVER}

Prebiehajúca diskusia z pohladu didaktikov poukazuje najmä na zložitost’ situácie. Evidentný rozdiel medzi látkovým množstvom a ostatnými základnými veličinami totiž netkvie primárne v tom, že mól je jedinou základnou jednotkou, o ktorej zaradenie do SI sústavy sa zaslúžili chemici. Rozdiel tkvie v samotnej podstate merania. Kým v ostatných prípadoch (dížka, hmotnost', čas) je podstatné, že meranie je porovnávaním pozorovaných a zaznamenaných hodnôt so stanovenou jednotkou, v prípade látkového množstva sa ukazuje, že jeho základnou jednotkou je samotný kus, reprezentovaný jednou diskontinuálnou entitou. Na ustanovenie hodnoty základnej jednotky látkového množstva teda podl'a nášho názoru nie je potrebná dohoda odbornej verejnosti, potrebná je v prípade ustanovenia hodnoty jej násobku - mólu. Otázne je, aký bude mat plánovaná redefinícia jednotiek vplyv na vzdelávanie. Pokial mól bude definovaný pomerne jednoducho a otázniky budú visiet najmä nad podstatou merania a teda aj hodnoty Avogadrovej konštanty, v prípade redefinície kilogramu bude situácia zložitejšia. Jeho definícia pomocou Planckovej konštanty je z didaktického hladiska vel’mi tažko uchopitelná a hrozí, že jej budú rozumiet len teoretickí fyzici (Price, 2011).

I ked’ nepredpokladáme, že didaktické hladiská by mohli zohrat významnú úlohu v diskusii k pripravovanej redefinícii základných jednotiek SI sústavy, sme presvedčení, že problémy vyučovania pomáhajú pripomenút etapy vývinu a lepšie pochopit’ pozadie pripravovaných zmien. $\mathrm{V}$ konečnom dôsledku je to dôvod na zamyslenie a možno jeden z posledných momentov na diskusiu pred dôležitým okamihom, ktorý ovplyvní vzdelávanie na dlhú dobu dopredu.

\section{PODĚKOVÁNí}

Príspevok vznikol s podporou projektu APVV č. 2014-0070.

\section{LITERATURA}

Barański, A. (2012). The Atomic Mass Unit, the Avogadro Constant, and the Mole: a Way to Understanding. Journal of Chemical Education, 89(1), 97-102.

BIPM. (2013). Draft 9th Brochure. Dostupné z http://www.bipm.org/utils/common/pdf/si_brochure_draft_ch123

De Bièvre, P. (2007). Numerosity Versus Mass. Accreditation and Quality Assurance, 12(5), 221-222.

De Bièvre, P. (2011). Integer numbers and their ratios are key concepts in describing the interactions of atoms and molecules. Accreditation and Quality Assurance, 16(3), $117-120$.

Furio, C. (2000). Difficulties in Teaching the Concepts "Amount of Substance" and "Mole". International Journal of Science Education, 22(12), 1285-1 303.

Held, L. (1985). Osvojovanie pojmu „látkové množstvo“: metodický list. Bratislava: Ústredný ústav pre vzdelávanie učitelov. 
Held, L. (2011). Konfrontácia koncepcií prírodovedného vzdelávania v Európe. Scientia in educatione, 2(1), 69-79.

Hill, T. P. (2011). Criticisms of the proposed "new SI". Accreditation and Quality Assurance, 16(8), 471-472.

Hill, T. P. \& Khruschov, V. V. (2013). Is there an objective need for an urgent redefinition of the kilogram and mole? Measurement Techniques, 56, 747-752.

Johansson, I. (2011). The Mole is Not an Ordinary Measurement Unit. Accreditation and Quality Assurance, 16(8-9), 467-470.

Leonard, B. P. (2011a). The avo (Av), gali (G), entity (ent) and exact dalton. Accreditation and Quality Assurance, 16(3), 173-174.

Leonard, B. P. (2011b). Alternative interpretations of the mole and the ideal gas equation. Accreditation and Quality Assurance, 16, 577-581.

Leonard, B. P. (2011c). Why the invariant atomic-scale unit, entity, is essential for understanding stoichiometry without 'Avogadro anxiety'. Accreditation and Quality Assurance, 16(3), 133-141.

Meinrath, G. (2011). The mole: definition versus practical use. Accreditation and Quality Assurance, 16(3), 167-170.

Mills, I. M. (1995). Unity as a unit. Metrologia, 31, 537.

Milton, M. J. T. (2011). Reasonable scope for change. Accreditation and Quality Assurance, 16(11), 575-576.

Padilla, K. \& Furio Mas, C. (2008). The Importance of History and Philosophy of Science in Correcting Distorted Views of "Amount of Substance" and "Mole" Concepts in Chemistry Teaching. Science and Education, 17(4), 403-424.

Pavese, F. (2011). Some Reflection on the Proposed Redefinition of the Unit for the Amount of Substance and of Other SI Units. Accreditation and Quality Assurance, 16(8-9), 161-165.

Petera, M. (1988). Mnohost a její měrné jednotky. Poznatky teoretické metrologie (teorie měřeni) využitelné $k$ logickému a srozumitelnému výkladu kvantifikačních pojmů a výpočtů $v$ chemii. Praha.

Price, G. \& De Bièvre, P. (2009). Simple Principles for Metrology in Chemistry: Identifying and Counting. Accreditation and Quality Assurance, 14(6), 295-305.

Price, G. (2010). Failures of Global Measurement System. Part 1: the Case of Chemistry. Accreditation and Quality Assurance, 15(7), 421-427.

Price, G. (2011). A skeptic's review of the New SI. Accreditation and Quality Assurance, 16(3), 121-132.

Richard, P. \& Ullrich, J. (2014). Joint CCM and CCU roadmap towards the redefinition of the SI in 2018. Dostupné z http://www.bipm.org/en/measurement-units/new-si/

Rocha-Filho, R. C. (2011). Reproposition of numerosity as the SI base quantity whose unit is the mole. Accreditation and Quality Assurance, 16(3), 155-159.

Schubertová, R. (2014). Induktívne osvojovanie pojmu látkové množstvo [Dizertačná práca]. Trnava: Trnavská Univerzita.

Slavíček, P. (2012). Avogadrova konstanta: 201 let počítání molekul. Chemické listy, 106, $1023-1028$. 
Sramko, T. et al. (1991). Chémia 8: pre 8. ročník základnej školy. Bratislava: Slovenské Pedagogické Nakladatelstvo.

Tifi, A. (2012). Dismissing the Mole Concept. La Chimica nella Scuola, 34(3), 368-371. Vicenová, H. \& Ganajová, M. (2012). Chémia pre 9. ročník základnej školy a 4. ročník gymnázia s osemročným štúdiom. Bratislava: EXPOL PEDAGOGIKA.

Romana SCHUBERTOVÁ, romana.schubertova@umb.sk

Univerzita Mateja Bela, Fakulta prírodných vied

Katedra biológie a ekológie

Tajovského 40, Banská Bystrica, Slovenská republika

L'ubomír Held, lheld@truni.sk

Trnavská Univerzita, Pedagogická fakulta

Katedra chémie

Priemyselná 4, Trnava, Slovenská republika 